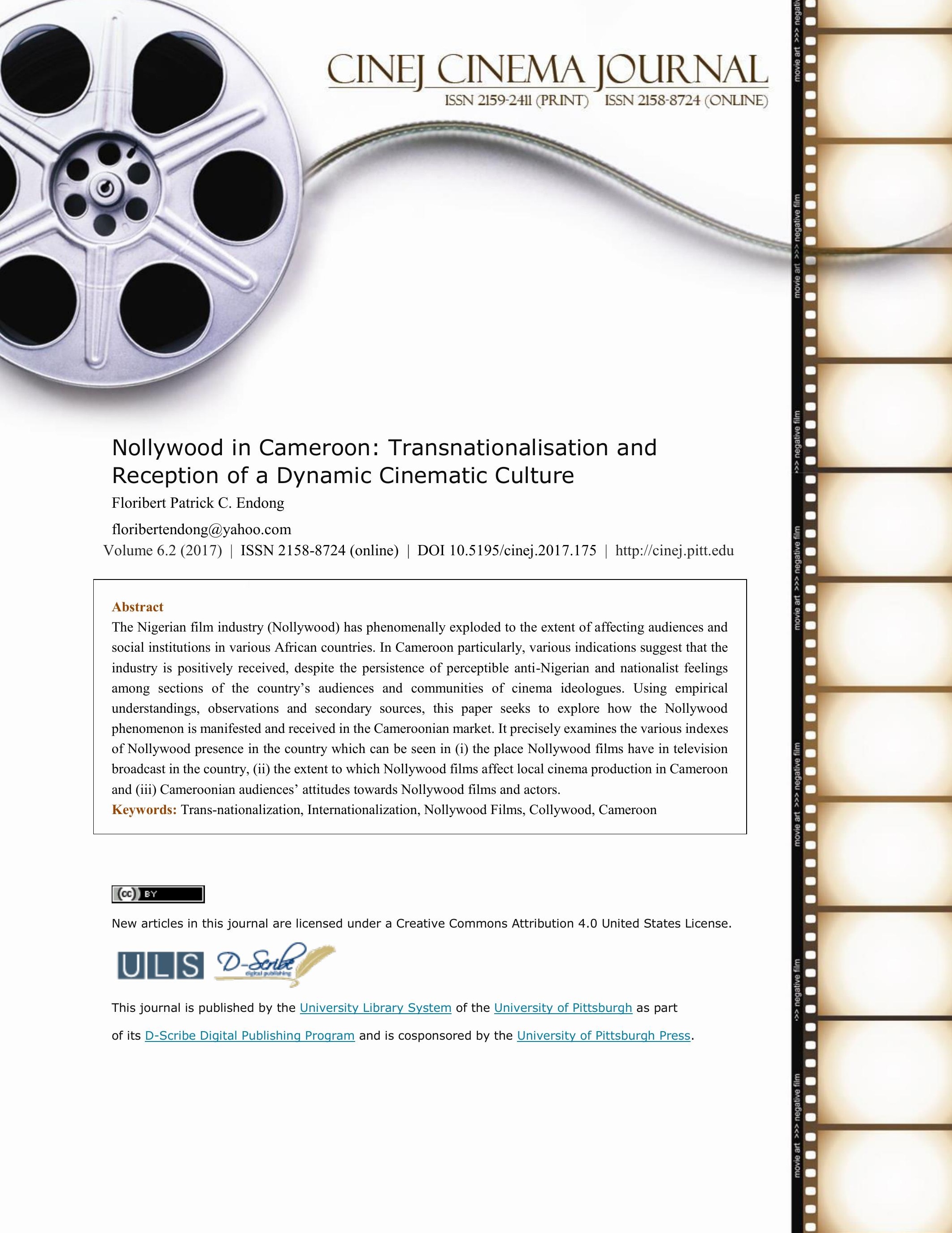




\section{Nollywood in Cameroon: Transnationalisation and Reception of a Dynamic Cinematic Culture}

\section{Floribert Patrick C. Endong}

\section{Introduction}

The growth of the Nigerian film industry brand named "Nollywood" has been immense and phenomenal. From various indications, the industry could rightly be described as a project which started as a weathered plant in the desert and which, in the blink of an eye, spectacularly grew to a huge baobab. In barely two decades, the industry has morphed into a pan-African affair, becoming the second largest cinema industry after Bollywood (UNESCO 2009). In spite of this spectacular growth, the industry has not been positively appraised by all pockets of critics and consumers. The prevalence of issues like bad technical quality and unprofessionalism in the industry has legitimized the negative - if not abysmal - reviews of good number of its critics. However, one thing remains certain: Nollywood has at least become a transnational cinematic culture. Some sources even describe it as a global phenomenon given the fact that it has spread its tentacles to some western and Asian climes as well as in some parts of the Caribbean region. Based on such a remarkable expansion and trans-nationalization, some observers, claim the industry may rightly be considered as one of the premier vectors of Nigeria's soft power in the international sphere, with immense potential to reveal important aspects of Nigerian cultures and thereby win more friends for Nigeria (Adefuye 2011). In the same line of argument, many observers have arguably described Nollywood as "the heartbeat of African cinema", a project which began life in an uncharacteristic manner and which later became a transnational phenomenon and the "Nigerian toddler who grew to robust global adult" among others (Kings \& Okome 2009; Dyikuk-Dyikuk 2015). 
Nollywood films have thus constituted a traveling idea and a multidimensional carrier of the African story. Audiences in Europe, America, Caribbean countries and (Black) Africa have increasingly become fans and consumers of Nollywood films. Corroborating this observation, Hayes (2011) notes that Nigerian video films constitute an important feature of television programming in countries like Namibia and Congo among others. They are on sale on the streets of Kenya. In New York, foreign publics such as Chinese and Caribbean nationals avidly consume them. In Holland, Nollywood stars are recognized on the street by people from surname and in London, they are hailed by Jamaicans. Through international broadcasters such as African Magic (a station broadcast all over Africa by DSTV) and Nollywood TV, most sub-Saharan and foreign audiences have been made to enjoy Nollywood movies and appreciate various aspects of the Nigerian ways of life.

The ubiquity of the Nollywood phenomenon is perhaps more perceived in Africa as there are palpable indexes of massive consumption of Nollywood films across the continent and evidences of Nollywood imperialism on the cinema and other cultural industries of other African countries. Nollywood imperialism is evident in the fact that most, if not all the emerging cinema industries in Black African countries are veritable offshoots or glaring imitations of the Nollywood phenomenon. As seen in Kollywood (in Kenya), Jollywood (in Johannesburg), Ghollywood (in Ghana), Collywood (in Cameroon), or Bongowood (in Tanzania), Nollywood has been serving as a model and inspiration for most national cinemas on African soil. The industry has equally been at the root of many social and attitudinal revolutions or "pathologies" in various parts of the continent. It is for instance taxed with “corrupting” local audiences' use of the English language in several countries. In Zambia more precisely, there is growing fear that Nollywood films inform children's improper pronunciation of English words (Seo 2015). Chanda cited by BBC (2010) notes that Nollywood films influence has been so infectious that in some circles, friends tend to 
pick up the distinctive West African (particularly Nigerian) accent whenever they joke or chat amongst themselves about happenings in their lives.

The Nollywood phenomenon has mostly been viewed by African publics (particularly Nigeria's close neighbors) as a "cultural insurgency" and a serious challenge to the independent growth and blossoming of their national cinema industries. On the basis of such observation, many nationalistic schools of thought have tended these last years to "dogmatically" profile and demonize Nollywood in neighboring climes. Akande (2013) succinctly underlines this fact when he remarks that:

In the early 2000 when the popularity of Nollywood held the entire African continent spell bound, one of the industries that was threatened by Nigeria's ingenuity was the Ghanaian film industry. Once described as spectres of an occult economy, [...] Nigerian films have been variously seen as having a negative impact on Ghanaian audiences. So bad it was that it became a bit difficult to say whether the bias was a result of the insurgence of Nollywood on Ghanaian terrain or simply a matter of morality. (p.22)

A similar situation may be envisaged in Cameroon where, according to Sa' aa (cited in BBC 2010), Nigeria has long been regarded as an imperialist-in-the making (given the sizable number of Nigerians living on Cameroonian soil); and where negative stereotypes of Nigeria(ns) have tended to affect popular perceptions of Nigerian products (Endong 2013). Indexes of Nollywood influences on African publics have therefore clearly varied with respect to countries, time and the nature of socio-cultural stereotypes Nigerian peoples are associated with in the respective countries. Using empirical understandings, observations and secondary sources, this paper seeks to explore how the Nollywood phenomenon is manifested and received in the Cameroonian market. It precisely examines the various indexes of Nollywood presence in the country which can 
be seen in (i) the place Nollywood films have in television broadcast in the country, (ii) the extent to which Nollywood films affect cinema production in Cameroon and (iii) Cameroonian audiences' attitudes towards Nollywood films and actors. This paper is anchored on the theory of trans-nationalization. Otherwise called internationalization, this theory is, according to Lorezen (2008), an aspect of globalization. The trans-nationalization or internationalization theory (in film studies) seeks to explain the explosion or growing export of films beyond their countries of origin.

\section{Rise, Growth and Translationalization of Nollywood: A Brief Review}

The origin of Nollywood is traced back to the 1960 when the very first set of films were produced by local filmmakers such as Hubert Ogunde, Ola Balogun, Adeyemi Afolayan, Jab Adu and Moses Olaiya among others. These filmmakers are today considered the fathers of the Nigerian film industry as they represented the first wave of local film producers. They debuted in their profession in the stage performance and gradually migrated to celluloid film production. Hubert Ogunde in particular is considered the father of Nigerian theatre thanks to his heavy contribution to the birth of the Nigerian film industry. As far back as 1945, he established the very first professional theatrical company named "Ogunde Theatre". Other important figures include Moses Olaiya and Sam Loco Efe (Adesokan 2013). These two are considered the fathers of modern Nigerian comedy thanks to their numerous pioneer filmic productions which brought the comedic film genre into existence in the country.

Though Nollywood as an industry started in the 1960s, it is in 1970 that its very first feature

film was produced. This film is Kongi's Harvest, written by Nobel literature Prize winner Wole Soyinka. Other films produced from 1970 to the 1980s include Alpha (1972), Bull Frog in the Sun (1974), Amadi (1975), Ajani Ogun (1975), Muzik Man (1976), Bisi, Daughter of the River (1977), 
Ija Ominira (1978), Aiye (1979), Kadara (1980), Jaiyesimi (1980) Efunsetan Aniwura (1981), Cry Freedom (1981), Ija Orogun (1982) Owo L'Agba (1982)

Despite the zeal of these filmmakers, the prohibitively high cost of production emerged as an obstacle to their profession. It is in a bid to surmount this obstacle and that of the closure of public theatres in the country (due to dwindling theatre audiences) that a new video film culture emerged in the country in the 1990s; causing Nollywood to grow in a dramatic magnitude. Indeed, to overcome the high cost of production, Nollywood film makers resorted to straight-to-video film production. The very first experiment of this practice is Ken Nnebue's Living in Bondage produced in 1992. The film is considered the very first film produced for commercial purpose and one of Nollywood greatest successes. With Nnebue's production as model, a cinema revolution was kickstarted and Nigeria's home video emerged. From this time, an ocean of sterling productions, commercial movies and blockbuster have been released to both local and international audiences. With time Nollywood progressively put Nigeria on global spotlight. It has just remarkably shifted from tape to big screen, from local to international nay, global presence. Though it has been enthused in various forums that continent Europeans and Americans will likely look askance at you if you mention the word "Nollywood", the industry has quickly "transnationalized". As early as in the first part of the 2000s, the industry was already known in some African metropolitan cities.

One of the earliest productions which have sold Nigeria to some international audiences is Osoufia in London starring popular Nigerian comedic actor Nkem Owoh. The film was released in 2003. Other major Nollywood films include Bamidele's Half of the Yellow Sun and Ije, considered by 2012 to be the highest-grossing Nollywood film of all times (Toyin 2013). Today, Nollywood is the second largest film industry in the world (in terms of volume), ahead of 
Hollywood and just after Bollywood. The industry produces over 50 films a week with movies which averagely incur less than $\$ 20,000$ per film (Oh 2014; Toyin 2013). It is a $\$ 600$ Million industry and the second employer in Nigeria after government. In other words, Nollywood officially generates an annual average, $\$ 600$ million for the Nigerian economy, "with most of these receipts coming from the African diaspora" (Oh 2014). In just about two decades, the industry has evolved from a national industry to a pan-African affair. It has spread its tentacles virtually in all Black African countries and various parts of Asia and the Caribbean region. While underline the trans-nationalization of Nollywood Hayes notes that:

The export of Nigerian films has been remarkable, even if most of the profits do not end up in the right hands. They are on television in Namibia and on sale on the streets in Kenya. In Congo, they are broadcast with the soundtrack turned down while an interpreter tells the story in Lingala or other languages. In New York, their biggest consumers are now immigrants from the Caribbean and African Americans, not Africans, and Chinese people are buying them too. In Holland, Nollywood stars are recognized on the streets of Suriname, and in London they are hailed by Jamaicans." (Haynes, 2007; pp.106-107)

The trans-nationalization of Nollywood has thus been aided by various factors. Some of these factors include satellite broadcasting, video film piracy and online broadcasting. International broadcasters such as South Africa based Africa Magic, Nollywood TV and My TV among others have served as strong vectors of the globalization - or at least internationalization of the Nollywood industry.

\section{Nollywood on Cameroon Based TV Stations}

In a study conducted in 2007, Ajibade had posited that Cameroonian audiences consume Nollywood films in four categories of spaces including private spaces, "dedicated spaces", tie-in spaces and found spaces. The consumption (viewing) of Nollywood films in such spaces had 
mostly involved the use of TV screens, VCDs and DVD players. This various spaces however represent just one mode through which Cameroon audiences have been consuming Nollywood as a good number of local (Cameroon based) and international broadcasters have been treating Cameroonian audiences to Nollywood features films as early as in the beginning of the years 2000s. One of the locally based television stations which has devoted a good portion of its programming to Nollywood films has been Spectrum TV (STV). As early as the debut of its existence, this station has made its religion to broadcast a Nollywood film every evening from Monday to Friday. Each film broadcast was re-broadcast the next day during afternoon periods, visibly to maximize viewership by Cameroonian audiences. STV's choice to prefer Nollywood films to western ones helped Africanize its programming. This made its programming remarkably different from those of its rival stations which either heavily depended on Hollywood movies or local theatrical productions.

The non-availability of statistics and official institutions devoted specifically to media programming in the country makes herculean to mathematically determine the proportion of airtime enjoyed by Nollywood films in the local Cameroonian media. However, a critical look at the broadcasting schedule of most private television stations such as STV, Canal 2 International and TV Max among others reveals that Nollywood films have come to constitute serious alternatives or complementary features to South American tele novellas and Asian series. Only the government owned CRTV Corporation (Cameroon Radio and Television) seems not to heavily rely on Nollywood movies to spice up its programming. The station appears more devoted to support local cinema and so, tends to broadcast more of Cameroonian productions (soap operas, short films and comedic films). Another local TV station which seems to devote much of its resources in favor of local filmic production is Canal 2. Though Nollywood films are observable 
features of TV programs in Cameroon, BBC World Service Trust (2010) posits that audiences seem to be more interested in Latin American and Asian series which are heavily broadcast on both state and private TV. Going by this observation it may be enthused that Nollywood still faces stiff competition from Asian and Latin American filmic productions in Cameroonian TV's programs.

\section{Impact of Nollywood on Collywood}

One clear index of Nollywood imperialism on Cameroonian cinema is the apparent "nigerianisation" of the Anglophone cinema sometimes nicknamed "AgloCam cinema". Through a number of studies, researchers have been able to establish the fact that the new frenzy among Anglophone film producers has been to copy Nollywood cinematic paradigm and to even superimpose them on their productions in total disregard to the principles or originality and creativity. Kanjo (2009) has for instance, underlines the fact that most rising Collywood stars tend to get inspiration from their Nollywood counterparts. In guise of explanation, he notes that: "if Cameroon is fond of Nollywood, it is also thanks to Jim Iyke, one of the most talented Nigerian actors. Jim has inspired many rising Cameroonian actors who say they must work hard and be like him". Many Cameroonian actors and film producers seek to emulate their Nigerian counterparts, even at the cost of "Nigerianising" their films.

In a study titled “Anglophone Cameroon Video Films: Boderline Cinema?” Nalowa (2015) similarly makes observations that intrinsically point to a heavy influence of Nollywood on Collywood. He posits that, at least two questionable cultures have marred Anglophone Cameroonian film productions in recent times. The first is that most Anglophone Cameroon films have their plots constructed as those of Nollywood films; and the second, most actors in the industry are fond of imitating their Nigerian counterparts in terms of body language, expression 
and use of interjections. Films like Neba Lawrence's Pink Poison Aicha's Royal Destiny, and Agbor Gilbert's Land of Shadows among others bear serious traits of typical Nollywood films. Based on such an observation, it may be plausibly enthused that Cameroon film producers' heavy dependence on Nigeria at all levels of production has tended to stifle originality and creativity in the Anglophone Cameroon film industry; making the Nollywood model to be popularly viewed as the ideal. Though it goes without saying that the act of blindly copying Nollywood film paradigms may be problematized, Nollywood remains an industry which may inspire the Cameroonian cinema industry. Some film scholars such as Mballa-Mballa (2014) have lauded Nollywood, presenting it as a model which, through benchmarking, could be used by Cameroonian film producers to reinvent the cinema industry in the country.

Another strong vector of Nollywood's influence on Collywood has been technical cooperation and partnerships between Nollywood actors and film makers with their Cameroonian counterparts. For some decades now, many Nigerian producers or actors have taken parts in Cameroonian film productions. And from many indications, their inputs in such productions have most often resulted in "nigerianising" or culturally (re)defining the productions at various degrees. Nigerian actors and superstar Emeka Ike for instance took part in a Collywood film production titled "Royal Destiny". In the production, he played more than the role of an actor. In an interview granted Kanjo (2010), he assessed his participation in the movie project thus: "I find interest in refining whatever is unrefined for international value" (p.34).

Like Ike, many other Nollywood actors' contributions to Collywood productions have been remarkable. The likes of Eucharia Anunobi, Emeka Ike and Jim Iyke among others, have starred various Cameroon made filmic productions. Others have been invited to feature in some cultural events in Cameroon. While some quarters are of the persuasion that such contributions have 
resulted in raising the standards of some Collywood productions, others have expressed concern over the potential of such participation to rather superimpose Nollywood cinematic paradigms in the Anglophone Cameroon video film industry (BBC 2010). Inasmuch as there is a clamor for non Nigerian interference in the (Anglophone) Cameroon film industry, the fact remains that Nollywood model informs the content of most local film projects in Cameroon. As the subsequent section is going to illustrate, it is even film narratives that adopt Nollywood thematic and stylistic characteristics (of voodoo, superstition, upward mobility and folk drama) that seem to seem to work best among the Cameroonian audience.

\section{Audiences Attitudes towards Nigerian Films and Actors}

A number of research works have demonstrated that Cameroon audiences a Nollywood sensitive and so will likely consume local productions fashioned according to Nigeria made films. Nalowa (2015) somehow observes this scenario when she enthuses that there is marked contradiction between the authentic local films which audiences clamor for and their heavy consumption of films fashioned after the Nollywood model. Though trustworthy statistic are still needed to clearly measure the volume of Nollywood film consumption in the country, it is observable that the Nollywood brand, the same as the made in Nigeria in general, has over the year penetrated the Nigerian market. It presence is undeniable. Sa'ah (cited in BBC 2010) makes allusion to such a situation when he notes that:

Truly, the [Nigerian] brand is here and no one can ignore it. Nollywood films are popular in homes, video clubs and TV channels. Cameroon's young film sector is benefiting from the expertise of their Nigerian friends who have jointly produced a few made in Cameroon video. Nigerian gospel music also has enveloped the place and the likes of P-Square [Nigerian hip-hop artistes] have been thoroughly embraced by the youths. 
Another index of Nollywood film mania among the Cameroonian audiences is their idolization of many Nollywood superstars. In effect, most Cameroonian audience (particularly in the Anglophone zones of the country) will "kill themselves" to have a glimpse of such actors as Ramsey Noah, Patience Ozokwo (aka Mama G) and Pete Odochie among others. In recent times, there have been reports of Nigerian actors being celebrated even in some traditional societies in Cameroon. Nigerian Actors Tchidi Tchikere, Walter Anga and comedian Klint Da Drunk were for instance, conferred with chieftaincy titles by the Mejan-Kom people of North-West Cameroon (Chioma 2016). These three Nigerian celebrities were respectively given the titles of Mbanfon, Guifon and Fuifon. The title conferring took place when the three visited Cameroon to premiere a movie. It has been reported that large pockets of the Cameroonian audiences have in some circumstances, manifested inordinate euphoria for specific Nollywood celebrities. Using Jim Iyke as an egregious example, Kanyi (2016) illustrate how Cameroonian apparent mania for Nollywood, particularly Nollywood actors has often led to chaotic situation. He notes that:

Jim Iyke was in Cameroon to shoot his new movie, when an army of female fans suddenly besieged him while on location. [...] as soon as the over anxious female fans learned that the $[\ldots]$ actor was shooting a movie in their country, they thronged the location in their tens of thousands and within minutes crowded him like bees on a honey pot - pressing to touch their idol. The situation almost got out of hand, [and without] the timely intervention of security men, Jim Iyke would have been mobbed by the eager Cameroonian fans. (Kanyi 2016, para 8)

Like Jim Iyke many other Nollywood actors pull crowds and are major attraction in cultural activities often organised on Cameroonian soil - notably the Anglophone Cameroon film festival. This mania, coupled with many other factors clearly suggests that Nollywood, as a brand and a trans-national cinematic culture, is positively received in Cameroon, though remarkable bastions 
of anti-Nigerian sentiments persist in the countries. As noted by Sa'ah, the dominant feeling among Cameroonian is that Nigeria is "an imperialist in-the-making" (cited in BBC). Similarly, Nalowa (2015) has underscored popular anti-Nigerian feelings among Cameroonian audiences manifested in their clamor for non-Nigerian interference in the young Cameroonian cinema. Considering these nationalist feelings among Cameroonian audiences, it may be interesting to see to what extent Nollywood has been influencing Cameroonians' perception of Nigeria as a country and its brands. So far, little or no attention has been devoted to this question.

\section{Conclusion}

Nollywood has phenomenally exploded and the consequences of its explosion are clearly visible in neighboring Cameroon. The industry has been able in just a blink of an eye to become a transnational cinematic culture strongly present in Cameroon. Official statistics on the volume of its consumption in Cameroon are not available. However, many indexes point to the fact that the industry is positively received by the Cameroonian audiences. This paper has reviewed over three of these indexes. It mentioned the fact that Nollywood films constitute serious components of TV programming in Cameroon. It equally highlighted the fact that Nollywood cinematic paradigms have quickly filtered through the Anglophone Cameroon video film industry, sometime stifling creativity and originality in local production. The paper equally highlighted the immense fan base Nollywood actors have in Cameroon. Such a growing fan base is an indicator that many Nollywood actors have become role models and inspiration not only for Collywood actors but equally for the Cameroonian youth. This against clearly illustrate the growing influence of Nollywood in Cameroon.

Despite the fact that Nollywood is a success story in Cameroon, bastions of anti-Nigerian feelings persist in Cameroon. A considerable section of the Cameroonian audience continues to 
perceive Nigeria as an imperialist country. It will be interesting for further studies to devote

attention to knowing the extent to which Nollywood films have reduced or intensified these antiNigerian feelings.

\section{BIBLIOGRAPHY}

Adefuye, A. (2011). Culture, diplomacy and the making of a new Nigeria. Lagos: CBAAC: Centre for Black African Arts and Civilization.

Adesokan, A. (2012). Nollywood and the idea of Nigerian cinema. Journal of African Cinemas $4(1), 81-98$.

Ajibade, B. (2007). From Lagos to Douala: The video film and its spaces of seeing. Postcolonial Text, 3(2), 1-14.

Akande, V. (2009). "If Sex is it, Let the Ghanaian Movie Rule!” The Nation, Saturday, January $16,22-35$.

BBC World Service Trust (2010). African Media Development Initiative. Cameroon country report context. London: BBC World Service Trust.

BBC (2010). How Nigeria has Affected the Rest of Africa. Retrieved March 21, 2016 from http://www.bbc.com/news/world-africa-11429067

Bilen-Onabanjo, S. (2013). The Rise of Nollywood. New African Magazine. July Edition, 2331.

Chioma R. (2016). "Nigerian Actors Bag Chieftaincies Titles in Cameroon”. Allure Vanguards, October 12 edition, 12.

Dyikuk-Dyikuk, J.J. (2015). The Nollywood narrative: Africa's golden goose on a global spotlight? Global Advanced Research Journal of Social Sciences, 2015: 49-53.

Endong, F. P. (2013). "Error in the English-French translation of advertising/marketing messages by Nigerian manufacturers: Effects on the image of the Nigerian product. CAJOLIS: Calabar Journal of Liberal Sciences, 17(1), 23-45.

Hayes, J. (2011) “African cinema and Nollywood: Contradictions”. Situations: Project of the Radical Imagination 4(1), 67-90.

Haynes, J. (2007). 'Nollywood': What's in a name?” Film International, 28(5.4): 106-108.

Kanjo, E. (2009). "I will marry a Cameroonian - Jim Iyke, Nollywood star. Tiptopstars Online Magazine, March 4, pp.1-5.

Kanjo, E. (2010). “'Cameroon will go places'. Emeka Ike, Nollywood actor says”. Tiptopstars Online Magazine, March 4, pp.1-4. 
Kanyi O. (2016). Nollywood star Jim Yike narrowly escaped being mobbed by female Cameroonian fans. Kanyi Okeke Blog. Retrieved March 12, 2017, from http://kanyiokeke.com/2012/03/nollywood-star-jim-iyke-narrowly.html

Kings, M. \& Okome, O. (2013). "Nollywood and its Diaspora: An introduction”. In Kings M. and Okome (Eds), Global Nollywood: The transitional dimensions on an African video film Industry. Chicago: Indiana University Press, 2013: 1-22.

Lorenzen, M. (2008). Creative Encounters. On the globalization of the film industry. Copenhagen: Copenhagen Business School/Imagine.

Mballa-Mballa, D. T. (2014). Benchmarking to: Du processus de production audiovisuelle: Transcription du modèle Nollywood sur le cinéma camerounais. MA Thesis Presented at the University of Yaoundé.

Nalowa, P. F. (2015). Anglophone Cameroon video films: Boderline cinema? Yaoundé: University of Yaoundé.

Oh, E. (2014). Nigeria's film industry: Nollywood looks to expand globally. Executive briefings on trade. (pp. 1-3), New York: United States International Trade Commission (USITC)

Seo, G. (2016). How Nollywood and Nigerian Movies Became 2nd Largest Film Industry in the World. NBM, Retrieved June 20, 2017, from http://nigeriamessageboard.com/how-nollywoodand-nigerian-movies-became-2nd- largest-film-industry-in-the-world/

Toyin, D. (2013). Resuscitating Nollywood. Sahara Reporters, Retrieved June 10, 2017, from http://saharareporters.com/2013/01/23/resuscitating-nollywood-toyin-dawodu 